\title{
Waste Water Treatment Plant for Sewage Water in the Sharrcem Plant
}

\author{
Halil Berisha $^{1 *}$, Shkurta Gashi ${ }^{1}$, Kostas Kouklidis ${ }^{1}$, John Mastoris ${ }^{1}$ and Kostis Dragasakis ${ }^{2}$ \\ ${ }^{1}$ Titan Sharrcem, Kosovo \\ 2 Titan Cement Group, Greece
}

\begin{abstract}
Water is increasingly recognized as a critical issue for sustainable development, becoming as important as carbon to corporate responsibility and reputation. Although the cement industry's overall 'water footprint' is relatively small compared to other sectors, the Cement Sustainability Initiative of the World Business Council for Sustainable Development (WBCSD/CSI) has recognized the importance of water and the need to take actions towards efficient water management, with developing standardizing practices and employing a risk-based assessment approach, mostly at local level where individual facilities and activities can have implications for other water users in the area. Sharrcem, a member of the Titan Cement Group, has made significant investments to upgrade its production facilities, the technological process and apply environmentally friendly technologies. Under this frame, Sharrcem implemented a project for the construction of a Waste Water Treatment Plant (WWTP) in the Cement Plant facilities, which has been successfully operating since early 2016. This paper discusses the technology applied at the new WWTP and the results achieved already, with significant improvement in the quality of the treated water, as compared to the previous situation where untreated wastewater was directly discharged to the nearby Dimce Stream. The WWTP project is a major investment of Sharrcem that aims to improve the quality of the discharged water effluents and thus prevent potential river pollution and overall protect the environment and the health of Sharrcem employees and local community. The WWTP operates with the Sequencing Batch Reactors (SBR) technology, is fully automated and has been also connected with few households of the neighboring community to treat also their sewage water. The plant can be expanded in the future - to connect with additional households - without increasing the size of the treatment tanks. One of the benefits of this project is that by removing a variety of contaminants from water it becomes usable again, depending on the nature of the contaminants and the end use of the water treated. According to the monitoring results the treated water that comes out of the WWTP fully meets quality requirements according to the EU and local limit values standards.
\end{abstract}

Keywords: waste water treatment, water quality, environment, health, local community

\section{Introduction/Background}

Sharrcem is located by in the southern part of Kosovo, close to the border with Former Yugoslav Republic of Macedonia (FYROM), in the municipality of Hani Elezit, and it is the only cement factory operating in the country. In 2010, Sharreem became a member of the Titan Group and remains the leading supplier of cement in Kosovo. A year after acquisition by the Titan Group, Sharrcem significantly upgraded its production facilities and technological process. This dynamic innovation was coupled with integration of highest standards at all operating levels. In 2014 Sharrcem received the Integrated Pollution Prevention and Control (IPPC) Permit, the first one to be issued in Kosovo. In addition, Sharrcem is certified with the ISO 14001Environmental Management System and the OHSAS ISO 18001 - Occupational Health and Safety Management System, ISO 9000 Quality Management System and Social Accountability SA 8000:2008. Beyond certifications, Sharrcem has received important awards for various Corporate Social Responsibility (CSR) initiatives.
According to the IPPC requirements for improvement programs and in compliance with Best Available Techniques (BAT) for the highest quality standards for waste water effluents, Sharrcem implemented the Waste Water Treatment Plant (WWTP) project within its premises, which was successfully finalized and put in operation in March 2016.

This project is also in alignment with the Titan Group's Environmental Policy. Titan has set targets and developed a vision with regards to Water Management in its Group Operations for Cement and Ready Mix, in order to increase awareness, improve efficiency, decrease and manage water risk. These objectives are in line with the Cement Sustainability Initiative of the World Business Council for Sustainable Development (WBCSD/CSI 2014a \& 2014b) that has recognized the importance of water and the need to take actions towards efficient water management. Relevant guidance and water risk assessment tools that have been developed by CSI and are used also by Titan include the Protocol for Water Reporting and the Global Water Tool (GWT) for Cement.

* Corresponding Author: H. Berisha, Halil.Berisha@sharrcem.com, phone: +381 290-385-500 ext.1114

Copyright @ 2017 Canamaple Academia Services, http://press.camdemia.ca

DOI: 10.15273/gree.2017.02.031 


\section{Description of Baseline Conditions}

The sewage network in the Sharrcem premises was built in the 1970's-80's and it also includes part of the community of Hani Elezit. There was no separate network for the atmospheric water and all water effluents were discharged with no treatment from four different discharge points directly to the Dimce Stream - that crosses through Sharrcem plant - and finally to the nearest recipient, the Lepenci River, which is at a distance of $200 \mathrm{~m}$ from the plant.

Based on regular monitoring of all discharge points, the quality of water effluents (coliform bacteria, BOD5, COD, TSS and $\mathrm{pH}$ content) did not satisfy the required national limits according to the legislation and IPPC permit for water effluent quality (Table 1 and Table 2).

Under this frame, Sharrcem took the decision and implemented a project for the construction of a Waste Water Treatment Plant (WWTP) in the Cement Plant premises.

The waste water quality output is evaluated through the following parameters:

- Coliform bacteria from fecal origin

- $\mathrm{BOD}_{5}$ - biological oxygen demand

- COD - chemical oxygen demand

- TSS - total suspended solids

- $\mathrm{pH}$

The WWTP was designed so as to meet the standards for the quality of waste water discharge according to the IPPC requirements, the Administrative Instruction AI 30/2014 and the EU regulative 91/271/EEC (1999) (Table 1).

Table 1. Water quality effluent requirements.

\begin{tabular}{lc}
\hline \multicolumn{1}{c}{ Parameter } & $\begin{array}{c}\text { Water quality requirements } \\
\text { according to the EU and local } \\
\text { standards (output of WWTP) }\end{array}$ \\
\hline $\mathrm{pH}$ & $6-8.5$ \\
\hline $\begin{array}{l}\text { Biochemical Oxygen } \\
\text { Demand (BOD } 5 \\
{ }^{0} \text { on }\end{array}$ & $25 \mathrm{mg} / \mathrm{l} \mathrm{O}_{2}$ \\
$20^{\mathrm{C})}$ Nitrification & $125 \mathrm{mg} / \mathrm{l} \mathrm{O}_{2}$ \\
$\begin{array}{l}\text { Chemical Oxygen } \\
\text { Demand (COD) }\end{array}$ & $35 \mathrm{mg} / \mathrm{l} \mathrm{O}_{2}(\mathrm{up} \mathrm{to} 10.000 \mathrm{EO})$ \\
\hline $\begin{array}{l}\text { Total Suspended } \\
\text { Solids }\end{array}$ & $60 \mathrm{mg} / 1$ \\
\hline
\end{tabular}

\section{Project Description}

The aim of the project was the improvement of water effluents quality, to serve as a sustainable solution and included: the construction of a new network pipeline $(200 \mathrm{~mm}$ diameter, $962 \mathrm{~m}$ total length) completely separated from the atmospheric water network; and the installation of a new Waste Water Treatment Plant for processing all waste water from the plant. A new collection point had to be formed to collect all waste water from the plant as well as from local residents surrounding the plant, thus providing to the nearby community the opportunity to treat their sewage water in the company premises.

\subsection{WWTP Location}

The appropriate location for setting the waste water treatment plant was chosen as to be close to the point of the final discharge to the Dimce stream and also to provide the option for potential expansion of the sewage system and the plant if necessary (Figure 1). The selected area covers approximately $0.22 \mathrm{Ha}$.

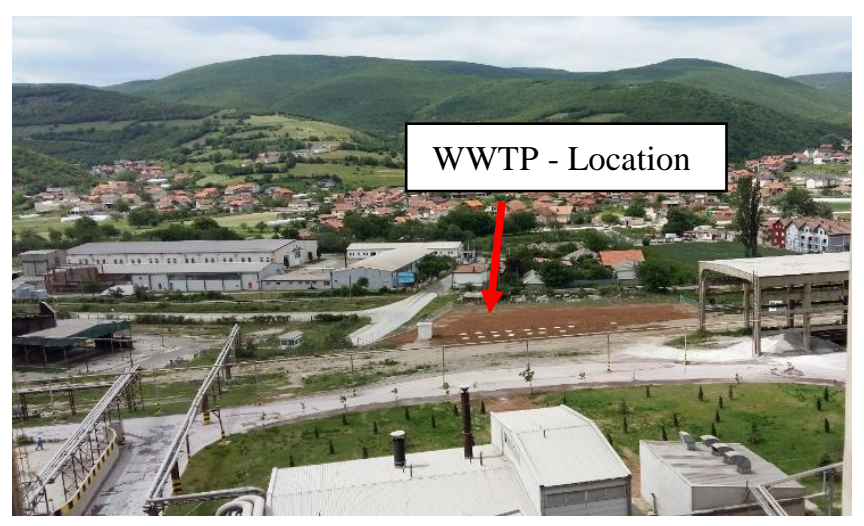

Figure 1. WWTP Location inside Plant premises.

\subsection{WWTP Purification Technology}

\subsubsection{Sequencing batch reactors (SBR)}

In the most basic form, SBR system is simply a set of tanks that operate on a fill-and-draw basis. Each tank in the SBR system is filled during discrete period of time and operates as batch reactor. After desired treatment, the mixed liquor is allowed to settle and the clarified supernatant is drawn from the tank. The essential difference between SBR and the continuous flow activate sludge system is that SBR carries out function such as equalization, aeration and sedimentation in a time rather in space sequence.

The SBR typically eliminates the need for primary and secondary clarifiers necessary in most treatment systems, which reduces operation and maintenance requirements. Therefore, pumps for return activated sludge are not required. In addition, anoxic basins, anoxic equipment, oxic basins and aeration equipment are accomplished in one reactor using aeration/mixing equipment. The SBR system is operated with controls, automatic valves and automatic switches and thus only daily routine inspection is required.

Each operating cycle of SBR reactor comprises five distinctive phases as follows: Fill, Mixed, React, Settle and Drainage or Decant phase.

\subsubsection{Working cycle in the SBR reactor}

FILL phase - Fill provides for the addition of influent to the reactor. During this phase, the influent wastewater is added to the biomass (i.e. mixed liquor suspended solid) which remained in the tanks from previous cycle. Depending on the treatment objective the Fill may be static mixed or aerated: 
- Static Fill (no mixing operation) results with minimum energy input and high substrate concentration at the end of this phase.

- Mixed Fill (mixing without aeration) results in denitrification, if nitrates are present, a subsequent reduction of BOD and energy input, and in the anoxic and anaerobic conditions required for biological phosphorous removal.

REACT phase - with the reactor full, the REACT phase begins. In general vigorous aeration is feature of this phase. However, as in FILL, the REACT phase required to be carried out in high dissolved oxygen concentration (aerated REACT) or in low oxygen concentration (mixed REACT). The time dedicated to REACT phase can vary from a low of zero to more than $50 \%$ of total cycle time. If organic removal is desired the aeration period can be as short as $15 \mathrm{~min}$. However, longer aeration periods in order of 4 hours or more are normally required for long term stability for the process and nitrification.

In the Sharrcem case it was recommended the REACT phase time in the SBR reactor to be $60 \mathrm{~min}$.

SETTLE phase - The SETTLE phase allows for separation of bio-solids from the treated effluent without increasing the volume of the secondary clarifier in the SBR reactor used for conventional continuous-flow activated sludge.

The major advantage of the SBR is its use as a clarifier, which allows for truly quiescent sedimentation conditions. Because all of the biomass remains in the tank until some frictions must be wasted, there is no need for underflow hardware normally found in conventional clarifiers.

DRAINAGE or DECANT phase - This is the withdrawal phase to discharge the clarified effluent from the reactor. The time dedicated to the DECANT phase can range from $5 \%$ to more than $30 \%$ of the total cycle time. The time for this phase should not be overly extended because of possible problems with rising sludge.

In the Sharrcem case the recommended DRAINAGE phase time in the SBR reactor was a maximum of 60 min., which was achieved utilizing an appropriate selection of pumps during the design and installation phase.

\subsection{Actions taken}

The WWTP project was preceded by an Environmental Impact Assessment (EIA) Study. The EIA was conducted in accordance with the requirements of national and international standards. The study has identified potential positive and negative impacts of the proposed project. The main possible adverse impacts recognized in the EIA referred to ground contamination from leakage/infiltration or flooding of wastewater and also nuisance during sludge hauling/handling (e.g. odor spread). The measures suggested by the EIA and taken during the design and construction of the WWTP to mitigate these potential impacts included:

- Proper concrete structures for the tanks and runoff diversion channels to prevent leakages.

- Protection of the whole network from the storm water to eliminate overflows.
- Installation of sufficient pumping equipment for quick and clean sludge hauling process.

On the other hand, as addressed in the EIA a positive outcome of the whole installation, besides the obvious expected improvement in the water effluents quality, is that planting of specific species of fast-growing trees on top of the treatment facility could be beneficial for biodiversity through the attraction of microorganisms, insects and even birds.

The WWTP project design and construction was made by an expert company from FYROM (Fluid Project-DOO Technical Project) and included the following phases (Figure 2):

- Topographic survey of the selected location.

- Geo-mechanical investigation of the area.

- Ground works with the excavation of pipe lines trenches and required manhole.

- Landscaping of areas where ground works were performed.

- Construction of concrete manhole and covers.

- Supply and installation of PE pipeworks.

- Ground and civil works, including concrete bottom plate.

- Installation of ground electricity supply for WWTP.

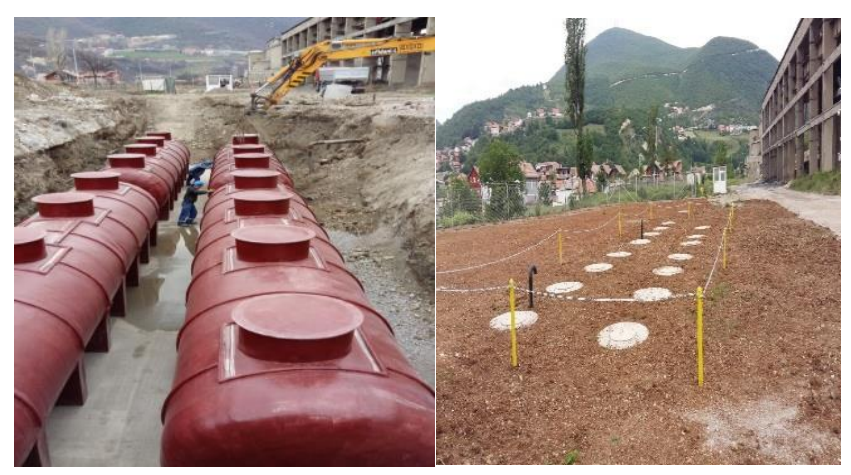

Figure 2. Civil work and final project.

\subsection{Outcomes from the WWTP operation}

\subsubsection{Raw wastewater}

According to the measurement of daily raw waste water generated the estimated wastewater flow rate is $100 \mathrm{~m}^{3} /$ day. The daily peak flow takes place in the middle of the day (1-3 $\mathrm{pm}$, after lunch). The detailed influent characteristics of the wastewater flowing into the current collection tank have been defined on the basis of the analyses of 3 composite samples collected from the main sewer line serving the Sharrcem plant compound. Average values are shown in Table 2 as the value before treatment.

\subsubsection{Waste water treatment quality}

The wastewater quality should meet the limits value of discharge waste water from treatments plant in the water body according to the administrative instruction AI 30/2014 of Ministry of Environment and also EU standards.

The waste water treatment quantity of effluent from SBR reactors is measured by flow meters installed in the outlet of 
WWTP before the discharge in to the surface water body (recipient) Dimce stream.

Table 2 presents the waste water quality parameters before (inlet) and after (outlet) treatment in WWTP-SBR technology, as annual average values of the regular analysis made on monthly basis. Also, the water inlet represents the quality of water of the previous situation, where no treatment was made and the wastewater was discharged directly to the stream. The parameters listed in the table show the significant reduction in all quality parameters, indicating the efficient and successful operation of the WWTP.

The output of the wastewater treatment unit is planned to be reused internally for irrigation purposes within the premises of the Sharrcem plant during the dry season.

Table 2 . Waste water quality before and after treatment.

\begin{tabular}{llrr}
\hline \multirow{2}{*}{$\begin{array}{c}\text { WWTP } \\
\text { Quality } \\
\text { parameters }\end{array}$} & $\begin{array}{c}\text { Limit Value } \\
\text { for effluent } \\
\text { according to } \\
\text { the AI } \\
\text { 30/2014 }\end{array}$ & $\begin{array}{c}\text { Waste } \\
\text { Water } \\
\text { Before } \\
\text { Treatment }\end{array}$ & $\begin{array}{c}\text { Waste } \\
\text { Water } \\
\text { After } \\
\text { Treatment }\end{array}$ \\
\hline pH & $6-8.5$ & 8.9 & 7.8 \\
\hline $\mathrm{TSS}$ & $60[\mathrm{mg} / \mathrm{L}]$ & 87.5 & 27.1 \\
\hline $\mathrm{COD}$ & $125\left[\mathrm{mg} / \mathrm{L} \mathrm{O} \mathrm{O}_{2]}\right.$ & 339.9 & 31.3 \\
\hline $\mathrm{BOD}_{5}$ & $25\left[\mathrm{mg} / \mathrm{L} \mathrm{O}_{2]}\right.$ & 161.3 & 14.5 \\
\hline TOC & $40[\mathrm{mg} / \mathrm{L}]$ & 121.2 & 9.8 \\
\hline
\end{tabular}

\section{Conclusions}

The Wastewater Treatment Plant (WWTP) is a major investment of Sharrcem that aims to improve the water effluents quality as a matter of caring for the environment and for the health of Sharrcem employees and nearby communities. The social aspect of this project is that Sharrcem has assisted part of the local communities by providing them with sewage water connectivity and treatment in the company premises.

Wastewater treatment processes are changing as researchers develop new techniques, which lead to improvements in purification, the speed of water treatment and uses for the waste products removed. Sharrcem's WWTP operates with SBR Technology at $100 \mathrm{~m}^{3} /$ day treating capacity, with fully automated control of pumps, valves, and automatic switches and minimum operation and maintenance requirements.

The outcomes of this project have already proven positive with significant improvement in the quality of water that is discharged to the stream that meets all legal requirements stemming from IPPC permit.

\section{Acknowledgement}

During all phases of the project implementation the companies "FLUIDI PROJECT DOO" and "FIDANI-L" showed a very professional commitment by complying with all requirements for health and safety at work and having efficient cooperation with all responsible managers of the plant, leading to the successful finalization of the project.

\section{References}

Administrative Instruction, 2014. Manners, parameters and limit values of wastewater discharge into public sewage network and in the water body.

EU, 1999. Regulative 91/271/EEC concerning urban wastewater treatment.

WBCSD/CSI, 2014a. Protocol for Water Reporting. http://www.wbcsdcement.org/index.php/keyissues/water/water-reporting.

WBCSD/CSI, 2014b. Global Water Tool (GWT) Cement Flyer for a corporate water risk assessment. http://www.wbcsdcement.org/index.php/keyissues/water/risk-assessment. 